\title{
Serum protein fractions in rheumatoid pneumoconiosis without arthritis
}

\author{
R. B. PAYNE \\ From the Department of Pathology, Welsh National School of Medicine, Cardiff
}

SYNOPSIS Fractionation of the serum proteins by filter-paper electrophoresis in 14 coal-miners who had the characteristic radiological opacities of rheumatoid pneumoconiosis but no evidence of rheumatoid arthritis showed a reduction in the mean level of albumin and increases in the alpha-2 and gamma-globulins compared with the values in non-arthritic miners with simple coalworkers' pneumoconiosis and in normal subjects. The changes were smaller than those found in miners with both rheumatoid arthritis and the radiological appearances of rheumatoid pneumoconiosis (Caplan's syndrome) and the mean levels did not differ significantly from those found in non-arthritic miners with progressive massive fibrosis. It is concluded that estimation of the serum protein fractions, unlike tests for rheumatoid factors, is unlikely to help in the differential diagnosis of unusual opacities seen on chest radiographs of miners without arthritis.

Caplan (1953) described an association between rheumatoid arthritis in coalworkers and the presence of multiple well-defined round opacities 0.5 to $5.0 \mathrm{~cm}$. in diameter in the chest radiograph. He pointed out that not all miners with characteristic opacities had rheumatoid arthritis, but many of them had been observed to develop arthritis after periods as long as 10 years. The characteristic pathology of the nodular pulmonary lesions giving rise to these opacities, which was described by Gough, Rivers, and Seal (1955), is the same whether or not the subject has rheumatoid arthritis (Gough, 1959), and positive rheumatoid factor tests have been found in a significant proportion of nonarthritic miners with characteristic radiological opacities (Caplan, Payne, and Withey, 1962). There is considerable evidence therefore that rheumatoid pneumoconiosis is a form of rheumatoid disease which can occur in the absence of arthritis.

The purpose of this investigation was to ascertain what changes are present in the serum fractions of non-arthritic miners with rheumatoid pneumoconiosis and to see whether they are sufficiently distinctive to help in the diagnosis of this condition.

\section{MATERIAL AND METHODS}

SELECTION OF SUBJECTS Serum specimens were available from 14 subjects without arthritis with opacities 'Present address: Department of Chemical Pathology, The University, Leeds 2.

Received for publication 28 March 1962. on the chest radiograph characteristic of rheumatoid pneumoconiosis. Twelve of these had been seen during an earlier investigation (Caplan et al., 1962). These 14 subjects were matched as closely as possible for age with three groups of 14 subjects with Caplan's syndrome (rheumatoid pneumoconiosis with rheumatoid arthritis), progressive massive fibrosis, and simple coalworkers' pneumoconiosis from among those seen during the earlier investigation, and with six healthy male non-miners aged 45 to 60 years.

The subjects with Caplan's syndrome had 'classical' or 'definite' rheumatoid arthritis as defined by Ropes, Bennett, Cobb, Jacox, and Jessar in a communication to the American Rheumatism Association (1959). All the other subjects had no history, symptoms, or signs of arthritis or arthralgia.

The subjects with rheumatoid pneumoconiosis with or without arthritis had multiple well-defined round opacities larger than $1.0 \mathrm{~cm}$. in diameter in the chest radiograph. The subjects with progressive massive fibrosis had few large opacities classified as category B or C (International Labour Office, 1959). The subjects with simple pneumoconiosis had small discrete radiological opacities up to $3 \mathrm{~mm}$. in diameter classified as category ' $p$ ' or ' $\mathrm{m}$ ' 2 or 3 (International Labour Office, 1959). The chest radiographs were read by Dr. A. Caplan.

Serum specimens from the 62 subjects were deepfrozen until used. The results of the sensitized sheep cell agglutination test of Greenbury (1957), the 
TABLE I

RESULTS OF RHEUMATOID FACTOR TESTS AND MEAN AGE

No. Positive Sheep Positive Bovine Cell Agglutination Globulin Latex Tests

Normal subjects

Simple coalworkers' pneumoconiosis

Progressive massive fibrosis

Rheumatoid pneumoconiosis without arthritis

Rheumatoid pneumoconiosis with rheumatoid arthritis

(Caplan's syndrome)

Cell Agglutination
Tests

Fixation Tests

bovine gamma globulin latex fixation test of Payne (1961), and the RA test (Hyland) and the mean age in each group are shown in Table $I$.

\section{ANALYSIS OF PROTEIN FRACTIONS}

Electrophoresis of $0.015 \mathrm{ml}$. of serum was carried out in a hanging strip tank using barbitone buffer $p H$ 8.6, ionic strength 0.05 , applying a constant current of $0.5 \mathrm{~mA}$ for each $5 \times 36 \mathrm{~cm}$. Whatman No. 1 filter paper strip for 18 hours. After drying at $120^{\circ} \mathrm{C}$. for $30 \mathrm{~min}$., the strips were stained with $0.2 \%$ lissamine green in $15 \%$ acetic acid for about $15 \mathrm{~min}$. and then washed with three changes of $2 \%$ acetic acid until the protein-free areas were white, and allowed to dry. Pencil lines were drawn across the strips in the areas of lightest staining between the protein bands and the strips were cut into fractions. This method of dividing the strips into fractions has been shown to give good reproducible results (Crook, 1956). Each fraction was placed in a stoppered tube containing $20 \mathrm{ml}$. of phthalate-sodium hydroxide buffer $p \mathrm{H} 6 \gamma 0$ and allowed to stand with occasional mixing for $\mathbf{3 0}$ minutes. The light absorptions of the eluted dye solutions were read in an E.E.L. portable colorimeter using filter 205 with phthalate-sodium hydroxide buffer as blank. The concentration of lissamine green was determined from a calibration curve prepared using the same batch of dye. The result for each fraction was expressed as the percentage to one decimal place of the total dye eluted from each paper strip.

\section{RESULTS}

Table II shows the mean and standard deviation of

0
0
0
$11(78 \cdot 6 \%)$

$12(85 \cdot 7 \%)$

$\mathbf{0}$
$\mathbf{0}$
$\mathbf{0}$
$\mathbf{7}(50 \cdot 0 \%)$

the serum protein fractions in the various groups which have been arranged in order of decreasing percentages of albumin. The significance of differ? ences between the mean values for each protei $\vec{x}$ fraction in the various groups of subjects has beetir determined by calculating it from the common variance for each pair.

Two groups, the normal subjects and the miner $\stackrel{\circ}{\Im}$ with Caplan's syndrome, show clear-cut differences from the others. The normal subjects had the highest mean albumin and the lowest alpha- $1 \frac{0}{\Phi}$ alpha-2, beta, and gamma globulins $(P<0.05$ fo beta-globulin; $\mathbf{P}<0.01$ for the other fractions) The miners with Caplan's syndrome had the lowest. mean albumin and the highest alpha-1, alpha-2 की gamma globulins $(P<\mathbf{0 . 0 1}$ for each fraction).

Of the remaining three groups, the non-arthridi miners with rheumatoid pneumoconiosis showed greatest abnormality and the miners with simplo pneumoconiosis the least. The mean albumin value् was lower $(P<0.01)$ and the apha-2 and gammæ globulins were higher $(P<0.05)$ in the first group $\overrightarrow{\vec{O}}$ The miners with progressive massive fibrosis ha申 values which fell between the values for these twథ groups and differed significantly from neither.

There was no significant difference between the mean values for the protein fractions in the sever non-arthritic miners with rheumatoid pneumo $\frac{3}{3}$ coniosis who had positive latex fixation tests and the seven who had negative tests $(P>0.10$ for eacl fraction).

TABLE II

SERUM PROTEIN FRACTIONS EXPRESSED AS PERCENTAGE OF TOTAL DYE ELUTED

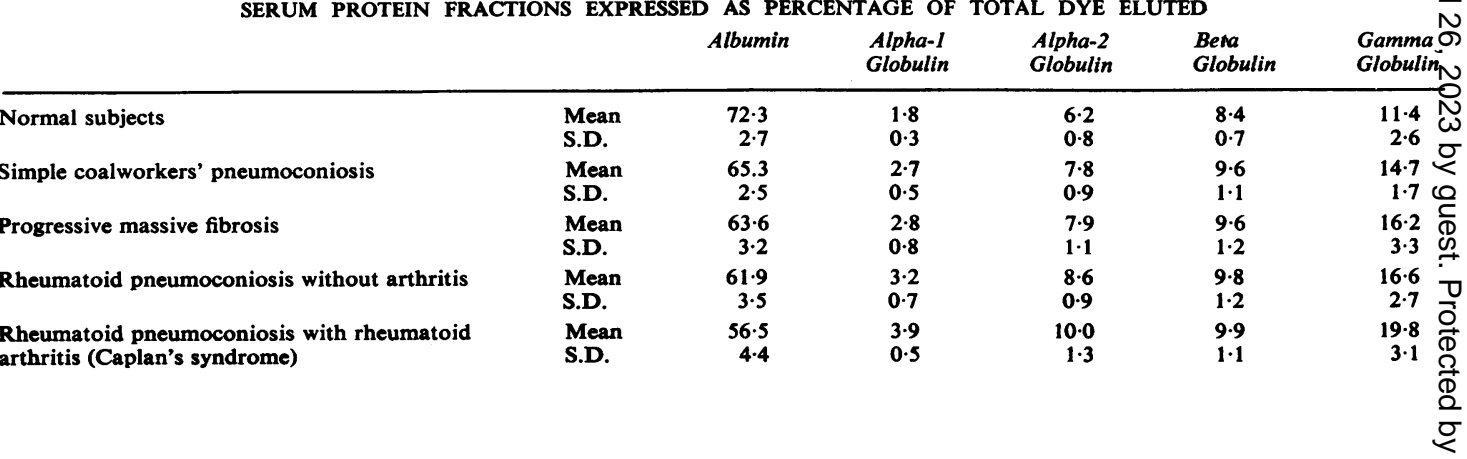




\section{DISCUSSION}

The serum protein fractions in rheumatoid pneumoconiosis have previously been investigated by Gorringe (1960) and Dickmans (1960). Gorringe was able to show an association in miners with Caplan's syndrome between changes in the levels of several fractions and the number and extent of chest opacities shown on radiographs independently of the severity of arthritis. As the number of opacities increased there was a reduction in albumin, an increase in the alpha-2 and gamma globulins, and a trend towards higher levels of beta globulin. Dickmans estimated the serum protein fractions in 29 non-arthritic miners with rheumatoid pneumoconiosis and in 16 miners with Caplan's syndrome. In the first group he found abnormally low levels of albumin in about one-sixth and high levels of the globulin fractions in about one-third. Abnormal levels of all fractions were found in about half of those with Caplan's syndrome. Neither worker investigated the changes in non-arthritic miners with simple pneumoconiosis or progressive massive fibrosis.

The importance of considering rheumatoid pneumoconiosis in the diagnosis of unusual chest opacities appearing on radiographs in miners even in the absence of arthritis has previously been stressed, and it has been shown that rheumatoid factor tests may help in the diagnosis (Caplan et al., 1962). Estimation of the serum protein fractions is unlikely to be of value in this type of problem because no significant differences were found in the present investigation between the changes in nonarthritic miners with rheumatoid pneumoconiosis and those with progressive massive fibrosis.

I am grateful to Dr. A. Caplan for reading the chest radiographs and providing some of the clinical data used in this investigation. The sensitized sheep cell agglutination tests were read by Dr. J. L. Withey.

\section{REFERENCES}

American Rheumatism Association (1959). Ann. rheum. Dis., 18, 49. Caplan, A. (1953). Thorax, 8, 29.

, Payne, R. B., and Withey, J. L. (1962). Ibid. In press.

Crook, E. M. (1956). In Ciba Foundation Symposium on Paper Electrophoresis, Pp. 132-148. Churchill, London.

Dickmans, H. (1960). Med. Welt (Stuttg.), p. 1276.

Gorringe, J. A. L. (1960). Serum Protein Changes in Caplan's Syndrome. M.D. thesis, University of Edinburgh.

Gough, J. (1959). In Modern Trends in Pathology, ed. D. H. Collins, p. 280. Butterworth, London.

$\longrightarrow$, Rivers, D., and Seal, R. M. E. (1955). Thorax, $10,9$.

Greenbury, C. L. (1957). Broadsheet No. 18 (New Series) of the Association of Clinical Pathologists.

International Labour Office (1959). Occup. Safety Hlth, 9, 63.

Payne, R. B. (1961). J. clin. Path., 14, 309. 